\title{
The Achievement of Physical Education Learning Objectives during COVID-19 Pandemic
}

\author{
Septian Williyanto \\ \{septianwilliyanto@upi.edu \\ Universitas Pendidikan Indonesia, Bandung, Indonesia
}

\begin{abstract}
The objectives of Physical Education include three aspects: cognitive, psychomotor, and affective. However, the Coronavirus 2019 outbreak is sweeping. The purpose of this study was to evaluate learning outcomes of Physical Education during the COVID-19 pandemic. This type of research is qualitative, the source of data for this study are Teachers, Students, and Parents. Data collection methods use observation, interviews, and documentation. Data analysis uses the triangulation method. Based on research, in the cognitive realm, primary school learning outcomes are 70\%, junior high 75\%, and high school $85 \%$. The Psychomotor Domain, for Elementary School, is 45\%, Middle School $60 \%$, and High School 75\%. And in the Affective domain, for Elementary School is $15 \%$, Middle School 30\%, and High School 65\%. This study concludes that learning outcomes during a pandemic are not optimal. Suggestion: the government provides equipment lending services to students who do not have and provide internet network facilities.
\end{abstract}

Keywords: physical education learning, covid-19 pandemic, learning.

\section{Introduction}

The achievement is something that you did or got after planning and working to make it happen, and that therefore gives you a feeling of satisfaction or the act of working to make this happen [1]. Learning objectives are defined as behavioral goals that are to be achieved or that can be done by students according to competence[2]. Learning objectives are a target to be made by teaching activities [3]. From the above definition, it can be taken an understanding that the achievement of learning objectives is an outcome obtained from what has been targeted in the learning process.

According to bloom's taxonomy, learning objectives are grouped into three domains; cognitive domain, psychomotor domain, and affective domain. Cognitive learning related to knowledge, psychomotor learning about actions and motor skills, and affective learning related to attitudes, feelings, and emotions [4],[5],[6] and [7]. So in the context of learning, all three domains must be the target set by the teacher for their students, including in physical education learning.

Physical education is a subject taught from Primary to High School. Basically, Physical education is an educational process through physical activities. Physical education is an educational process through physical activities designed to improve 
physical fitness, develop motor skills, knowledge, and healthy and active living behaviors, sportsmanship, and emotional intelligence [3], [8]. Physical education has a vital role in the promotion and acquisition of students' healthy behavior [9]. Physical education programs at schools provide a crucial environment for intervention in developing motoric competencies of school-age children and overall physical fitness, while also stimulating competency motivation to engage in physical activity[10]. However, currently, physical education learning is forced to be done online at home due to a coronavirus outbreak (COVID19).

Coronavirus $(\mathrm{CoV})$ is a large family of viruses that can infect birds and mammals, including humans, this virus is zoonotic, meaning this is a disease that can be transmitted between animals and humans such as Rabies and Malaria[10]. According to WHO (World Health Organization), this virus causes diseases ranging from mild flu to more severe respiratory infections such as MERS-CoV and SARSCoV. Currently, the coronavirus has spread almost all countries in the world, including in Indonesia. By 31 March 2020, there have been 1,528 confirmed COVID-19 cases in Indonesia and 136 deaths related to the disease[8]. COVID-19 also has a significant impact on education. One of the efforts made by the government is the issuance of a learning policy in a manner online in preventing the spread of COVID-19 through the MENDIKBUD Circular Letter No 36962 / MPK.A / HK / 2020 [11].

Online learning is a technology-based learning model through distance learning by using internet network facilities to be able to interact online[12]. In online education, the teacher and students are required to access the website using an updated device and internet support. Online learning tsunamis have occurred almost throughout the world during the COVID-19 pandemic[13]. Teachers and educators, as essential elements in teaching, are required to undertake unprecedented mass migrations from traditional face-to-face education to online education or distance education [14], [15].

From some of the above reviews, a conclusion can be drawn that the achievement of Physical Education learning objectives is grouped into three domains, namely; cognitive, psychomotor, and affective. The cognitive domain is related to thinking abilities, the psychomotor domain is similar to movement skills, and the affective domain is relevant to students' feelings. However, with the coronavirus outbreaks of physical education, learning must be done online. Some examples of journal articles that are reviewed in this study are:

The research of [16]. The purpose of this study was to identify obtaining information on the constraints of the online teaching and learning process at home as a result of the presence of a COVID-19 pandemic. The study used an exploratory case study method, and the research approach used a qualitative case study method that was used to obtain information on the constraints and consequences of the COVID-19 pandemic on teaching and learning activities in elementary schools. The results of this study are that there are several obstacles experienced by students, teachers, and parents in teaching and learning activities.

The research of [17]. The purpose of this study as a general review of learning during the COVID-19 pandemic. This research uses descriptive analysis study method. The results of this study are in the form of conclusions which are reviewed from several scientific articles. The outcome of this study is that online learning is the best solu- 
tion. Still, it needs further research considering that the ability of the facilities provided by parents to students is different.

The article of [18]. The article aims to describe the extent of the implementation of the cognitive domain, affective domain, and psychomotor domains in grade III Primary School quantitatively. This study does during regular learning, or not in an emergency. This study uses a quantitative to describe cognitive, affective, and psychomotor learning outcomes into numbers.

The article of [8]. This article aims to explain the condition of the coronavirus outbreak in Indonesia. This research uses an analysis study method. The results of this study are the conclusions which are reviewed from several scientific articles. The results of the discussion in the form of an appeal to the community to remain silent at home to reduce spread COVID-19.

The article of [19]. This article is about the co-19 prevention movement and the things that must be done in prevention efforts. This research uses an analysis study method. The results of this study are in the form of conclusions which are reviewed from several scientific articles. The outcome is the movement to prevent rather than treat the good is still applied and not too late, considering that because the spread of the virus is swift and has claimed many lives.

\section{Methodology}

The type of study is quantitative with a descriptive approach/ survey. The purpose of the descriptive research method is to provide a systematic description or description related to the phenomenon being investigated. The object purpose of this study is a Primary School, Junior High School, and Senior High schools in COVID-19 affected areas. The source of the data in this study is teachers, students, and parents. The data collecting method is to use an observation technique, interview, and documentation. The data analysis used is the triangulation method by taking a conclusion. Data collection instruments in this study are :

\subsection{Cognitive Variable Instrument}

The cognitive domain can be measured in two ways, namely subjective and objective tests; individual tests are usually in the form of essays. Still, in practice, these tests cannot cover all the material to be tested[14]. The instrument in this study used an objective analysis.

Table 1. Cognitive Variable Instrument [18]

\begin{tabular}{lll}
\hline No. & Assessment Aspects & Respondent \\
\hline 1 & Knowledge & Teacher, Students, \& Parents \\
2 & Comprehension & Teacher, Students, \& Parents \\
3 & Application & Teacher, Students, \& Parents \\
4 & Analysis & Teacher, Students, \& Parents \\
5 & Synthesis & Teacher, Students, \& Parents \\
6 & Evaluation & Teacher, Students, \& Parents \\
\hline
\end{tabular}




\subsection{Psychomotor Variable Instrument}

Assessment of psychomotor learning outcomes in this study can be done using direct observation and evaluation of student behavior in the teaching-learning process, and the tools used in the measurement of the psychomotor domain are observation[14]. The psychomotor area is an area that deals with aspects of skills that involve the functioning of the nervous and muscular systems and mental functions [3].

Table 2. Psychomotor Variable Instrument [18]

\begin{tabular}{lll}
\hline No. & Assessment Aspects & Respondent \\
\hline 1 & Basic Motion & Teacher, Students, \& Parents \\
2 & Physical Skills & Teacher, Students, \& Parents \\
3 & Skilled Motion & Teacher, Students, \& Parents \\
4 & Perceptual Skills & Teacher, Students, \& Parents \\
5 & Reflex & Teacher, Students, \& Parents \\
\hline
\end{tabular}

\subsection{Affective Variable Instrument}

The instrument used in the measurement of affective domains is observation, because observations in taking data are not limited to people, but can also be used in the natural environment or the natural environment[14]. Classifying this affective domain into five levels, namely: (1) Receiving or paying attention (2) Responding, (3) Valuing, (4) Regulate or organize, and (5) Characterization with a value or group of profits[13].

Table 3. Affective Variable Instrument [5]

\begin{tabular}{lll}
\hline No. & Assessment Aspects & Respondent \\
\hline 1 & Receiving & Teacher, Students, \& Parents \\
2 & Responding & Teacher, Students, \& Parents \\
3 & Valuing & Teacher, Students, \& Parents \\
4 & Organization & Teacher, Students, \& Parents \\
5 & Characterization & Teacher, Students, \& Parents \\
\hline
\end{tabular}

\section{$3 \quad$ Results}

\subsection{The Results}

The policy of social distancing to minimize the spread of COVID-19 requires that all education units activate learning even though schools are closed. School closures are the most effective solution to reduce the spread of epidemics to students. During the pandemic COVID-19, online learning was the only way to continue the rest of the semester. In this study, interviews were conducted online by applying the COVID-19 preventive health protocol through the WhatsApp and zoom applications. The study was conducted in April and May 2020, in the area with the red zone COVID-19 status. The research sample selection uses a purposive sampling technique. 


\subsection{Physical Education Learning in Primary School}

Information and multimedia technology are developing rapidly in all fields, including education. The most crucial goal of technology is to facilitate the work of everyone, especially for a teacher. However, in reality, there are many Physical Education teachers at the primary school level who have not utilized this facility. Physical education teachers complain that many students do not have smart phones so that physical education learning at the primary school level is mostly not implemented. In the study there were only $15 \%$ of teachers who carried out learning with the following results;

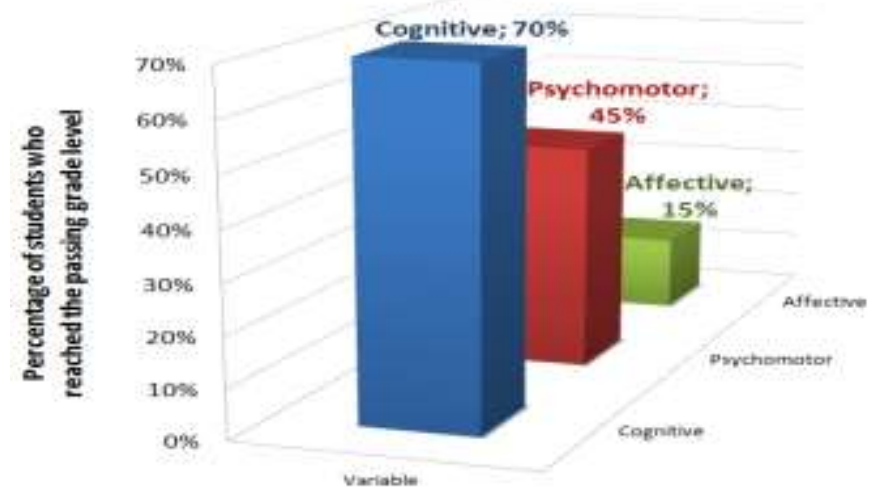

Fig. 1. Primary School Learning

Based on the results of the study, it was found that three out of nine Physical Education teachers in Elementary Schools only give assignments while studying at home by working on "Student Worksheets." But the teacher never asks for the work, because of the limitations of the communication media. And one teacher gives assignments in the form of videos and questions sent via WhatsApp. Another teacher does not give the task because the problem is the students do not have the facilities and infrastructure at home that can use, for example, Racket, ball, Long jump sandbox, and others

\subsection{Physical Education Learning in Junior High Schools}

The learning media is a supporting factor in Physical Education learning, meaning that the better the media used, the better the prospects for success in learning. The learning media is always developing, so teachers and students need to be able to use it. At the junior high school level, online-based physical education learning is not the best solution. The problem is, many students don't have smart phone devices, so students have to replace smart phones with their parents. Students' parents also found another problem; they felt that the assignment given by the teacher was quite heavy so that parents often did not understand when asked about learning material by their children. In junior high school learning research, the following results were obtained. 


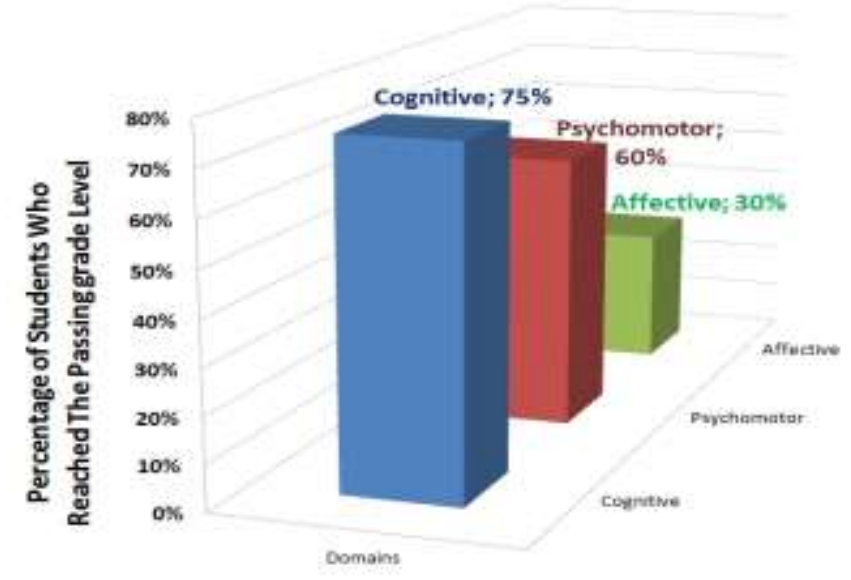

Fig. 2. Junior High School Learning

\subsection{Physical Education Learning in Senior High Schools}

In addition to facilities, infrastructure is also needed to support the Physical Education learning process. The required infrastructure includes the field, goal post, net, pole net, teacher's room, and others. Apart from devices, internet networks are essential things that must be present when learning online, because if the device is not connected to the internet network, then the machine will not function if used to communicate. The results of the study show the following data.

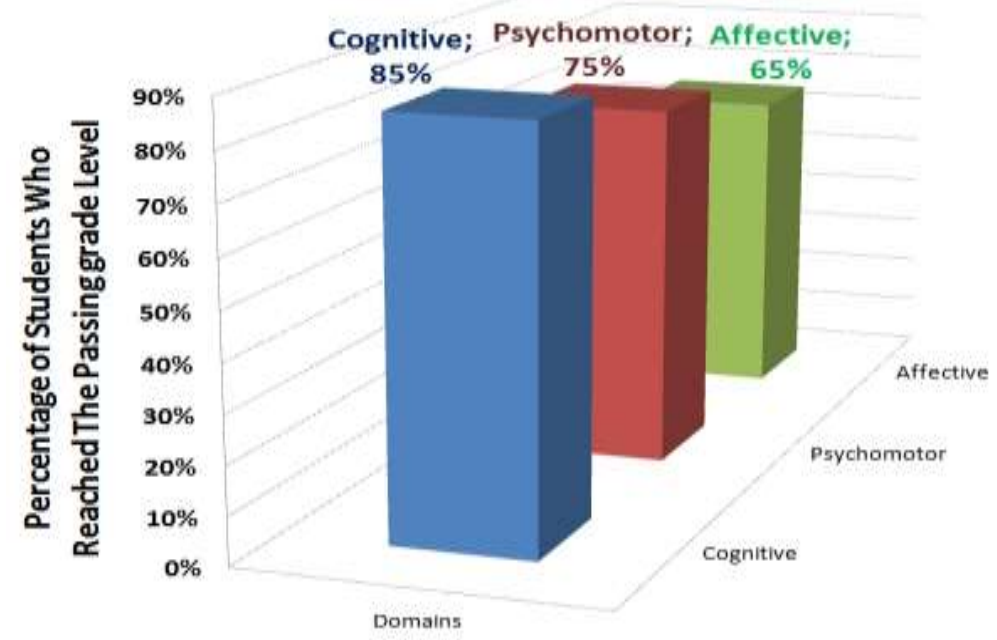

Fig. 3. Senior High School Learning 


\section{Discussion}

The results showed that in the cognitive realm, the learning outcomes achieved up to $70 \%$ at the Primary School level, $75 \%$ at the Junior High School, and $85 \%$ at the Senior High School level. However, in the realm of psychomotor learning outcomes, only reached $45 \%$ for the Primary School level, $60 \%$ for the Junior High School level, and $75 \%$ for the Senior High School level. As for the Affective domain, the learning outcomes reach $15 \%$ for Primary School, 30\% for Junior High School level, and 65\% for Senior High School level.

The percentage of learning outcomes shows that physical education learning is not ready if it has to be done online, many things must be prepared to start from the availability of devices, internet channel support, and also human resources. According to [17], this needs to be evaluated and adapted to local conditions, given the ability of parents to provide different online learning facilities. From the development of information obtained, many teachers are entirely unaware of the latest communication technology at this time, so teachers do not provide learning material to their students. The statement is the same as the results of research from [16], the impact felt by teachers is that not all are proficient at using internet technology or social media as a learning tool, some senior teachers have not been fully able to use devices or facilities to support online learning activities and need assistance and training first.

From this information, it can be concluded that the development of technology in education is critical. A teacher and students must have the ability to be able to operate the latest devices that can support the educational process. Teachers and educators, as essential elements in teaching, are required to undertake unprecedented mass migrations from traditional face-to-face education to online education or distance education [14], [15]. This presents a challenge to all elements and levels of education to keep the class even though the school has closed [17].

\section{Conclusion}

The conclusion in this study is that the goal of online-based physical education implemented in schools affected by COVID-19 has not been reached to the fullest. This happens because several factors influence it. For example, the lack of facilities is the cause of decreased enthusiasm for students themselves. Many students do not collect assignments given by the teacher. They feel that while at home, there are no teachers or supervisors. It happened because their parents were also busy looking for other income to shop for daily needs. Various problems that occur cause a decrease in student enthusiasm, even resulting in reduced student presence in the learning process.

Suggestions from researchers: The government and the school should find a solution from the evaluation of learning happening in our country today. In this case, efforts that can be done by the government are by providing loaning services for students who do not have a device, and providing services in the form of internet channel assistance so that communication in learning will continue well. 


\section{Acknowledgements}

We would like to thank Faculty of Sport and Health Education, Universitas Pendidikan Indonesia, Indonesia for the funding.

\section{References}

[1] https://dictionary.cambridge.org/dictionary/english/achievement. [Accessed: 23-Jun2020].

[2] http://biosaefful.blogspot.com/2013/05/definisi-manfaat-dan-tujuan-pembelajaran.html. [Accessed: 24-Jun-2020].

[3] Sulaiman, Strategi Pembelajaran Pendidikan Jasmani, Olahraga, dan Kesehatan Dengan Pendekatan Sistem, Pertama. Semarang: CV. Swadaya Manunggal, 2016.

[4] A. Noorhidawati A, S. G. Ghalebandi, and R. S. Hajar, "How Do Young Children Engage with Mobile Apps? Cognitive, Psychomotor, and Affective Perspective Computers \& Education How do young children engage with mobile apps ? Cognitive , psychomotor, and affective perspective," Comput. Educ., vol. 87, no. August, pp. 385-395, 2015.

[5] http://www.unco.edu/cetl/sir/stating_outcome/documents/Krathwohl.pdf. Last accessed. [Accessed: 24-Feb-2014].

[6] http://www.rockymountainalchemy.com/whitePapers/rma-wp-learning-taxonomies.pdf. [Accessed: 24-Feb-2014].

[7] http://www.edpsycinteractive.org/topics/cognition/bloom.pdf. Last accessed.

[8] S. Setiati, and M.K. Azwar, "COVID-19 and Indonesia," no. April, 2020.

[9] A. Granero-Gallegos et al., Importance of Physical Education: motivation and motivational Climate, Vol. 132,. Elsevier, Science Direct: Procedia - Social and Behavioral Sciences.

[10] X. Gu, Y. Chen, A.W. Jacson, and T. Zhang, "Impact of a pedometerbased goal-setting intervention on children's motivation, motor competence, and physical activity in physical education," Phys. Educ. Sport Pedagog., 2017.

[11] https://www.kemkes.go.id/article/view/20031900002/Dashboard-Data-Kasus-COVID-19di-Indonesia.html.

[12] N. Putranti, "Cara Membuat Media Pembelajaran Online Menggunakan Edmodo," J. Pendidik. Inform. dan Sains, vol. 2(2), 139-, 2016.

[13] Goldschmidt, K, \& Msn, P.D, "The COVID-19 pandemic : Technology use to support the wellbeing of children," J. Pediatr. Nurs., vol. xxxx, 3-5, 2020.

[14] Bao, W, "COVID-19 and online teaching in higher education: A case study of Peking University," no. March, pp. 113-115, 2020.

[15] Basilaia, G, and Kvavadze, D, "Transition to Online Education in Schools during a SARS-CoV-2 Coronavirus (COVID-19) Pandemic in Georgia," Pedagog. Res., vol. 5(4), 2020.

[16] A, Purwanto, R, Pramono, M, Asbari, P.B, Santoso, L.M, Wijayanti, C.C, Hyun, and R.S, Putri, "Studi Eksploratif Dampak Pandemi COVID-19 Terhadap Proses Pembelajaran Online di Sekolah Dasar," J. Educ. Psychol. Couns., vol. 2 No. 1, pp. 1-12, 2020.

[17] L. D. Herliandry and M. E. Suban, "Jurnal Teknologi Pendidikan Pembelajaran Pada Masa Pandemi Covid-19," vol. 22, no. 1, pp. 65-70, 2020.

[18] I. Nurbudiyani, "Pelaksanaan Pengukuran Ranah Kognitif, Afektif, Dan Psikomotor Pada Mata Pelajaran Ips Kelas Iii Sd Muhammadiyah Palangkaraya," Anterior J., vol. 13 No. 1, no. Desember 2013, pp. 88-93, 2013.

[19] W. Zendrato, "Gerakan Mencegah Daripada Mengobati COVID-19," J. Educ. Dev. Inst. Pendidik. Tapanuli Selatan, vol. 8 No.2, no. Edisi Mei, 2020. 